\title{
Body composition and fatty acid profile of musculus longissimus dorsi in growing pigs fed a diet supplemented with grass meal
}

\author{
S. Raj, G. Skiba, M. Sobol' ${ }^{1}$ and D. Weremko \\ The Kielanowski Institute of Animal Physiology and Nutrition Polish Academy of Sciences \\ 05-110 Jabłonna, Poland
}

KEY WORDS: pigs, grass meal, body composition, intramuscular fat, fatty acids profile
Received: 14 September 2015

Revised: $\quad 30$ October 2015

Accepted: 25 November 2015
${ }^{1}$ Corresponding author: e-mail: m.sobol@ifzz.pl
ABSTRACT. The present study aimed to establish the effects of grass meal and duration of feeding it on the carcass chemical composition, and on the intramuscular fat (IMF) concentration and fatty acid composition of the musculus longissimus dorsi (MLD) in 48 pigs growing from 25 to $105 \mathrm{~kg}$ body weight (BW). The pigs were fed a commercial diet (C) or a diet containing $20 \%$ grass meal (GM). Changes of the chemical components in the carcass and intramuscular fat of the MLD were estimated using the comparative slaughter method. The animals were slaughtered at 50,80 and $105 \mathrm{~kg} \mathrm{BW}$. Pigs consuming the grass meal diet grew more slowly (by $9.2 \% ; P=0.007$ ), but they had similar amounts of protein, ash and water (average $9.9,1.8$ and $35.9 \mathrm{~kg}$, respectively) and less (by 18.4\%; $P=0.001$ ) fat in the carcass compared with those fed the commercial diet. Pigs fed the GM diet had approximately $20 \%$ less IMF $(P=0.003)$, lower $(P=0.024)$ concentration of saturated fatty acids $(S F A)$ and higher $(P=0.047)$ concentration of polyunsaturated fatty acids (PUFA) in the MLD than pigs fed the $C$ diet. The GM pigs also had a higher concentration of C18:3 n-3 (linolenic acid; $P=0.047$ ) and tended to have a lower $(P=0.091) C 18: 2 n-6 / C 18: 3 n-3$ ratio in the MLD than $C$ pigs. The PUFA/ SFA ratio remained low, but was more beneficial in the pigs fed the GM diet compared with those fed the $C$ diet ( 0.40 vs 0.35 , respectively; $P=0.102$ ).

\section{Introduction}

Pork plays an important role in the economy and human nutrition. To be competitive on the market, production efficiency must be maximized and must take into consideration the quality aspects of meat. The quality concept has become dynamic and includes diversity, functionality, nutritional value and safety. Furthermore, animal environmental and welfare aspects and production systems are also considered components of meat quality. Existing strategies allow meat and meat products to be modified by adding ingredients considered beneficial for health that eliminate or reduce components considered harmful. To improve the nutritive value of meat, its fatty acid composition has been manipulated by dietary means to increase the proportion of unsaturated fatty acids. Several studies have focused on how the fatty acid composition of pork is influenced by different feeds. In general the relative levels of polyunsaturated fatty acids (PUFA) increase when pigs are administered feed admixed with highly unsaturated components 
(Raj et al., 2010; Kouba and Sellier, 2011). Some authors (Webb and O'Neill, 2008), however, point out that the unsaturated fatty acids deposited in pork fat through supplementing feed with fat (e.g., vegetable oil) are readily oxidized, and that this is one of the factors responsible for deterioration of meat quality. In this context, the appropriate reasonable use of roughage in pig feeding is of interest. Jonsäll et al. (2000) found a relatively high level of PUFA in the loins of free-grazing outdoor-reared pigs compared with the loins of pigs fed conventional feed. Also studies by Jakobsen (1995) and Świątkiewicz and Hanczakowska (2007) indicate that addition of fresh grass, silage or herbs to conventional diets altered the fatty acid composition of pork to one with a ratio of unsaturated to saturated fatty acids that is more beneficial for humans. Hansen et al. (2006) showed that pigs fed a diet with clover silage had a significantly higher meat content (by $8.2 \%$ ) in the carcass, as well as thinner loin backfat (by approximately $22 \%$ ) in comparison with pigs fed according to Danish recommendations.

Therefore, it may be assumed that the type of feed manipulation may affect the fat and meat/protein content in the body of pigs. This may occur not only in the whole body/carcass, but also in the muscle, and consequently the profile of fatty acids in the intramuscular fat (IMF) may be modified. In the current study, grass meal was added to the diet as a roughage component introducing PUFA into the commercial diet.

The aim of this study was to establish the effect of supplementing a commercial diet with grass meal and the duration of feeding on the growth rate, content of chemical components in the carcass, intramuscular fat concentration, and fatty acid composition in the musculus longissimus dorsi of growing pigs.

\section{Material and methods}

The experimental procedures used throughout this study were performed in accordance with Polish ethical guidelines and approved by the Local Ethics Committee for Animal Experimentation in Warsaw (Poland).

The environmental conditions in the piggery, i.e. air temperature $\left(18-20^{\circ} \mathrm{C}\right)$, humidity $(60-70 \%)$ and air flow $\left(0.2-0.4 \mathrm{~m} \cdot \mathrm{s}^{-1}\right)$ were regulated by a Fancom ventilation system (Fancom BV, NK Panningen, the Netherlands) and were in compliance with Polish law (Regulation of the Minister of Agriculture and Rural Development, 2003).

\section{Animals and diets}

Forty-eight crossbreed gilts ( $\hat{\sigma}$ Duroc $\times q$ Large White) with a body weight (BW) from 25 to $105 \mathrm{~kg}$ were kept individually in $2.6 \mathrm{~m}^{2}$ pens equipped with an automatic feeder and nipple drinker. The animals were fed ad libitum two granulated diets: commercial (low-fibre diet, group $\mathrm{C}, \mathrm{n}=24$ ) or experimental containing 20\% grass meal (high-fibre diet, group $\mathrm{GM}, \mathrm{n}=24$ ). The $\mathrm{C}$ diet was based on cereals and soyabean meal, whereas the GM diet was formed by mixing diet C with $20 \%$ of commercial grass meal. The grass meal added to the diet was a roughage component, moreover, it introduced more PUFA. Standardized ileal digestible amino acids and metabolizable energy of the diets were calculated according to Degussa (2001) and RFES (2003). Feed intake and BW were measured weekly.

Changes of the chemical components in the carcass and of the musculus longissimus dorsi (MLD) were determined using the slaughter method described by Kotarbińska (1971). Within each group the pigs were slaughtered at $50( \pm 1.3 ; \mathrm{n}=8)$, $80( \pm 2.4 ; \mathrm{n}=8)$ and $105( \pm 2.9 ; \mathrm{n}=8) \mathrm{kg} \mathrm{BW}$. The composition and nutritive value of diets, concentrations of fatty acids and carcass composition are presented in Tables 1, 2 and 4, respectively.

\section{Sample collection}

The pigs were slaughtered after $16 \mathrm{~h}$ of starvation using an electrical stunning (STZ 3 apparatus, P.P.H. MASTER Sp. J., Poland) at the experimental slaughterhouse of the Kielanowski Institute of Animal Physiology and Nutrition Polish Academy of Sciences in Jabłonna (Poland). The same procedure was used regardless of slaughter BW. The blood from exsanguination was collected. After slaughter, the viscera were removed and the gastrointestinal tract was emptied. The carcass and non-carcass parts (viscera, blood and hair) were weighed separately. Carcasses were chilled for $24 \mathrm{~h}$ at $4{ }^{\circ} \mathrm{C}$ and next the right half-carcass was dissected into soft/edible tissues (ST - meat and fat), bones and skin. Inedible parts (IP - bones, head, feet and skin) were autoclaved for $12 \mathrm{~h}$. Further, the ST and IP parts were homogenized and samples $(500 \mathrm{~g})$ were taken to determine chemical components. The protein, fat, ash and water contents in the carcass were calculated as a sum of their content in the ST and IP. From the left half of each carcass the entire MLD was separated, ground and a random sample of $500 \mathrm{~g}$ was taken and homogenized. Next, all samples of MLD were packed into vacuum bags, frozen and kept at $-40^{\circ} \mathrm{C}$ until analysis of the ether extract (fat) and fatty acid composition. 
Table 1. Composition and nutritive value of diets fed to pigs

\begin{tabular}{|c|c|c|}
\hline \multirow{2}{*}{ Indices } & \multicolumn{2}{|c|}{ Diet/group ${ }^{1}$} \\
\hline & $\mathrm{C}$ & GM \\
\hline \multicolumn{3}{|l|}{ Ingredient, $\mathrm{g} \cdot \mathrm{kg}^{-1}$} \\
\hline barley & 309 & 247 \\
\hline wheat & 297 & 238 \\
\hline triticale & 90 & 72 \\
\hline maize & 50 & 40 \\
\hline soyabean meal & 180 & 144 \\
\hline rapeseed meal & 50 & 40 \\
\hline grass meal & - & 200 \\
\hline premix $^{2}$ & 24 & 19 \\
\hline \multicolumn{3}{|l|}{ Chemical composition, $\mathrm{g} \cdot \mathrm{kg}^{-1} \mathrm{DM}$} \\
\hline organic matter & 941.8 & 931.7 \\
\hline crude ash & 58.2 & 68.3 \\
\hline crude protein & 211.7 & 190.6 \\
\hline ether extract & 24.6 & 24.6 \\
\hline crude fibre & 42.8 & 85.4 \\
\hline NDF & 59.3 & 57.2 \\
\hline ADF & 151.0 & 254.0 \\
\hline $\mathrm{N}$-free extractives & 662.7 & 631.1 \\
\hline \multicolumn{3}{|l|}{$\begin{array}{l}\text { Nutritive value } \\
\text { standardized ileal digestible }{ }^{3}, \mathrm{~g} \cdot \mathrm{kg}^{-1}\end{array}$} \\
\hline protein & 120 & 100.3 \\
\hline lysine & 8.20 & 6.78 \\
\hline methionine & 2.46 & 2.15 \\
\hline threonine & 4.52 & 3.97 \\
\hline tryptophan & 1.40 & 1.16 \\
\hline metabolizable energy ${ }^{4}, \mathrm{MJ} \cdot \mathrm{kg}^{-1}$ & 13.1 & 11.6 \\
\hline lysine/metabolizable energy, $\mathrm{g} \cdot \mathrm{MJ}^{-1}$ & 0.63 & 0.59 \\
\hline \multicolumn{3}{|c|}{$\begin{array}{l}{ }^{1} \mathrm{C} \text { - commercial diet, } \mathrm{GM} \text { - diet containing grass meal; }{ }^{2} \text { addition of } \\
2.5 \% \text { or } 1.9 \% \text { premix introduce to } 1 \mathrm{~kg} \text { diet: IU: vit. A } 1500 \text {, vit. } \mathrm{D}_{3} 300 \text {; } \\
\text { mg: Fe } 60, \mathrm{Zn} 50, \mathrm{Cu} 30, \mathrm{Mn} 30, \mathrm{I} 0.30 \text {, Se } 0.20 \text {, vit. E } 40 \text {, vit. } \mathrm{K}_{3} 2.0 \text {, } \\
\text { vit. } \mathrm{B}_{1} 2.0 \text {, vit. } \mathrm{B}_{2} 2.5 \text {, vit. } \mathrm{B}_{6} 2.0 \text {, vit. } \mathrm{B}_{12} 0.02 \text {, biotin } 0.11 \text {, folic acid } \\
0.6 \text {, nicotinic acid } 15, \text { calcium-D pantothenate } 10 \text {, choline chloride } 500 \text {; } \\
\text { g: Ca } 2.8, \mathrm{P} 0.07, \mathrm{NaCl} 3 ;{ }^{3} \text { standardized ileal digestibility protein and } \\
\text { AA calculated according to the Degussa (2001); }{ }^{4} \text { calculated according } \\
\text { to RFES (2003) }\end{array}$} \\
\hline
\end{tabular}

\section{Chemical analysis}

The contents of dry matter, ash, crude protein, crude fibre and ether extract in the diets were determined according to AOAC (2011; procedure No.: 934.01, 942.05, 984.13, 978.10, 920.39, respectively). Lipids of diets and MLD samples were extracted with chloroform-methanol (2:1) according to the method described by Folch et al. (1957) and methyl esters were prepared by esterification with thionyl chloride (4\% in methanol) and extraction with n-heptane. Fatty acid methyl esters were separated by gas chromatography on a GC-2010AF Shimadzu gas chromatograph (SHIMADZU Europa GmbH, Duisburg, Germany), equipped with a BPX70 capillary column (length $60 \mathrm{~m}$, internal diameter $0.25 \mathrm{~mm}$, film thickness $0.25 \mu \mathrm{m}$ ). The operating conditions were: carrier gas, helium; split ratio, 1:100; injector and detector temperature, $260^{\circ} \mathrm{C}$; the initial column temperature of $140^{\circ} \mathrm{C}$ was held for $1 \mathrm{~min}$, then increased to $200^{\circ} \mathrm{C}$ at a rate of $4^{\circ} \mathrm{C} \cdot \mathrm{min}^{-1}$, then increased to $220^{\circ} \mathrm{C}$ at a rate of $1{ }^{\circ} \mathrm{C} \cdot \mathrm{min}^{-1}$. Individual fatty acid peaks were identified by comparison with the Supelco 37 Component FAME Mix (SUPELCO, Bellefonte, USA) commercial standard.

\section{Statistical analysis}

Statistical analysis was performed using Statgraphics Centurion software (version 16.1.18; 2011; StatPoint Technologies Inc. Warrenton, USA). The effect of diets and duration of feeding on the chemical components of the carcass and fatty acid profile in the MLD of pigs were analysed using two-way ANOVA. The significance of differences between means was tested with the least significance $(P<0.05)$ using Student's t-test.

\section{Results}

\section{Performance and content of chemical components in the carcass}

The metabolizable energy and digestible protein (standardized) contents in the commercial diet were higher than in the grass-meal feed (13.1 vs $11.6 \mathrm{MJ}$ and $120 \mathrm{vs} 100 \mathrm{~g} \cdot \mathrm{kg}^{-1}$, respectively; Table 1). The differences in the fatty acid composition between the $\mathrm{C}$ and GM diet were considerable, with more highly unsaturated fatty acids in the GM feed. The C diet contained $9.4 \mathrm{~g} \cdot \mathrm{kg}^{-1}$ of PUFA, while the GM diet contained $13.8 \mathrm{~g} \cdot \mathrm{kg}^{-1}$ (Table 2). Content of saturated fatty acids (SFA) did not differ between groups (average $5.3 \mathrm{~g} \cdot \mathrm{kg}^{-1}$ ), however, the mono-

Table 2. Concentration of SFA, MUFA, PUFA and particular fatty acids in diets, $\mathrm{g} \cdot \mathrm{kg}^{-1}$

\begin{tabular}{llc}
\hline Fatty acids (FA) & \multicolumn{2}{l}{ Diet/group } \\
\cline { 2 - 3 } & $\mathrm{C}$ & $\mathrm{GM}$ \\
\hline Total FA & 21.2 & 21.9 \\
SFA $^{2}$ & 5.4 & 5.1 \\
MUFA $^{3}$ & 6.2 & 4.0 \\
PUFA $^{4}$ & 9.4 & 13.8 \\
PUFA/SFA $^{5}$ & 1.74 & 2.7 \\
$14: 0$ & 0.05 & nd \\
$16: 0$ & 4.6 & 4.4 \\
$16: 1 \mathrm{n}-7$ & 0.07 & 0.05 \\
$18: 0$ & 0.6 & 0.7 \\
$18: 1 \mathrm{n}-9$ & 5.6 & 3.9 \\
$18: 2 \mathrm{n}-6$ & 8.0 & 5.0 \\
$18: 3 \mathrm{n}-3$ & 1.4 & 8.8 \\
$20: 1 \mathrm{n}-9$ & 0.11 & 0.05 \\
$20: 3 \mathrm{n}-6$ & $\mathrm{nd}$ & $\mathrm{nd}$ \\
$18: 2 \mathrm{n}-6 / 18: 3 \mathrm{n}-3$ & 5.7 & 0.57 \\
\hline
\end{tabular}

${ }^{1}$ see Table $1 ;{ }^{2}$ SFA - saturated fatty acids; ${ }^{3}$ MUFA - monounsaturated fatty acids; ${ }^{4}$ PUFA - polyunsaturated fatty acids; ${ }^{5}$ PUFA/SFA - ratio of polyunsaturated to saturated fatty acids; nd - not determined 
Table 3. Performance of animals during growing period

\begin{tabular}{|c|c|c|c|c|c|c|c|}
\hline \multirow[b]{2}{*}{ Indices } & \multirow{2}{*}{$\begin{array}{l}\text { Body } \\
\text { weight } \\
\text { (BW) }\end{array}$} & \multicolumn{2}{|c|}{ Diet/group 1} & \multirow[b]{2}{*}{ Mean } & \multicolumn{3}{|c|}{ Significance } \\
\hline & & $\mathrm{C}$ & GM & & SEM & BW diet & $\begin{array}{l}\text { BW } x \\
\text { diet }\end{array}$ \\
\hline \multirow{4}{*}{$\begin{array}{l}\text { Feed intake, } \\
\mathrm{kg} \cdot^{\prime} \text { day }{ }^{1}\end{array}$} & $25-50$ & 1.91 & 1.93 & $1.92^{\mathrm{A}}$ & & & \\
\hline & $25-80$ & 2.25 & 2.31 & $2.26^{\mathrm{B}}$ & 0.030 & 0.0100 .165 & 0.059 \\
\hline & 25-105 & 2.50 & 2.63 & $2.56^{C}$ & & & \\
\hline & Mean & 2.22 & 2.29 & 2.25 & & & \\
\hline \multirow{4}{*}{$\begin{array}{l}\text { ME intake }{ }^{2} \\
\mathrm{MJ} \text { day }^{-1}\end{array}$} & $25-50$ & 25.0 & 22.4 & $23.7^{\mathrm{A}}$ & & & \\
\hline & $25-80$ & 29.5 & 26.8 & $28.2^{\mathrm{B}}$ & 0.048 & 0.0100 .049 & 0.225 \\
\hline & 25-105 & 32.7 & 30.5 & $31.6^{\mathrm{C}}$ & & & \\
\hline & Mean & $29.1^{\mathrm{A}}$ & $26.6^{B}$ & 32.8 & & & \\
\hline \multirow{4}{*}{$\begin{array}{l}\text { Digestible } \\
\text { protein intake, } \\
\mathrm{g} \cdot \text { day }^{-1}\end{array}$} & $25-50$ & 292 & 247 & $270^{A}$ & & & \\
\hline & $25-803$ & 345 & 296 & $321^{\mathrm{B}}$ & 5.6 & 0.0080 .009 & 0.147 \\
\hline & $25-1053$ & 383 & 337 & $360^{c}$ & & & \\
\hline & Mean & $383^{B}$ & $337^{\mathrm{A}}$ & 360 & & & \\
\hline \multirow{4}{*}{$\begin{array}{l}\text { Average daily } \\
\text { gain, } \mathrm{g}^{\cdot} \text { day }^{-1}\end{array}$} & $25-50$ & 889 & 762 & $826^{A}$ & & & \\
\hline & $25-80$ & 919 & 843 & $881^{B}$ & 25.6 & 0.0090 .007 & 0.842 \\
\hline & $25-105$ & 943 & 894 & $919 c$ & & & \\
\hline & Mean & $917^{\mathrm{B}}$ & $833^{c}$ & 875 & & & \\
\hline \multirow[t]{4}{*}{ Days } & $25-50$ & 28 & 32 & $30^{A}$ & & & \\
\hline & $25-80$ & 60 & 65 & $63^{\mathrm{B}}$ & 1.35 & 0.0100 .05 & 0.325 \\
\hline & 25-105 & 86 & 91 & $89^{c}$ & & & \\
\hline & Mean & $58^{a}$ & $63^{b}$ & 60.5 & & & \\
\hline \multirow{4}{*}{$\begin{array}{l}\text { Feed conver- } \\
\text { sion ratio, } \mathrm{kg} \\
\text { feed } \mathrm{kg} \text { gain }^{-1}\end{array}$} & $25-50$ & 2.16 & 2.55 & $2.36^{\circ}$ & & & \\
\hline & $25-80$ & 2.45 & 2.74 & $2.60^{\mathrm{b}}$ & 0.06 & 0.0350 .047 & 0.095 \\
\hline & $25-105$ & 2.65 & 2.95 & $2.80^{\circ}$ & & & \\
\hline & Mean & $2.40^{a}$ & $2.70^{\mathrm{b}}$ & 2.58 & & & \\
\hline
\end{tabular}

${ }^{1}$ see Table $1 ;{ }^{2} \mathrm{ME}$ - metabolizable energy intake; ${ }^{\mathrm{ABC}, \text { abc }}$ means with different superscipts within a row (body weight) or column (diet/group) are significantly different at $P<0.01$ or $P<0.05$, respectively

unsaturated fatty acids (MUFA) content was lower in the GM than in the $\mathrm{C}$ diet $\left(4.0 \mathrm{vs} 6.2 \mathrm{~g} \cdot \mathrm{kg}^{-1}\right)$. The pigs fully accepted the feed supplemented with grass meal, which accounted for approximately $10 \%$ of the total energy intake.

The average daily feed intake did not differ between groups of pigs, however, pigs fed GM diet consumed on average $8.6 \%$ less $(P=0.049)$ metabolizable energy and approximately $12 \%$ less $(P=0.009)$ digestible protein than those of group $\mathrm{C}$ (Table 3). Moreover, the average daily gain of pigs fed the GM diet was lower by $9.2 \%(P=0.007)$ than pigs fed the GM diet. Consequently, GM pigs took 5 days more $(P=0.05)$ to reach $105 \mathrm{~kg} \mathrm{BW}$, and the feed conversion ratio was worse as they need 0.30 $\mathrm{kg}$ more $(P=0.047)$ feed per kilogram body gain than $\mathrm{C}$ pigs.
Table 4. Empty body weight (EBW) and content of chemical components in pigs carcass, $\mathrm{kg}$

\begin{tabular}{|c|c|c|c|c|c|c|c|c|}
\hline \multirow[b]{2}{*}{ Indices } & \multirow{2}{*}{$\begin{array}{l}\text { Body } \\
\text { weight } \\
\text { (BW) }\end{array}$} & \multicolumn{2}{|c|}{ Diet/group ${ }^{1}$} & \multirow[b]{2}{*}{ Mean } & \multirow{2}{*}{ SEM $^{2}$} & \multicolumn{3}{|c|}{ Significance } \\
\hline & & C & GM & & & BW & diet & $\begin{array}{l}\text { BW } x \\
\text { diet }\end{array}$ \\
\hline \multirow[t]{4}{*}{ EBW } & 50 & 46.6 & 46.7 & $46.6^{A}$ & & & & \\
\hline & 80 & 76.3 & 74.0 & $75.1^{\mathrm{B}}$ & 0.345 & 0.001 & 0.029 & 0.071 \\
\hline & 105 & 99.4 & 98.6 & $98.9^{c}$ & & & & \\
\hline & Mean & $74.1^{\mathrm{b}}$ & $73.1^{\mathrm{a}}$ & 73.6 & & & & \\
\hline \multirow[t]{4}{*}{ Carcass } & 50 & 37.9 & 37.6 & 37.7 & & & & \\
\hline & 80 & 65.0 & 61.7 & 63.4 & 0.385 & 0.003 & 0.001 & 0.078 \\
\hline & 105 & 85.2 & 83.8 & 84.4 & & & & \\
\hline & Mean & 62.7 & 61.0 & 61.9 & & & & \\
\hline \multirow[t]{4}{*}{ Protein } & 50 & 6.5 & 6.4 & $6.4^{\mathrm{A}}$ & & & & \\
\hline & 80 & 10.1 & 10.3 & $10.2^{B}$ & 0.142 & 0.001 & 0.196 & 0.200 \\
\hline & 105 & 13.0 & 13.7 & $13.3^{c}$ & & & & \\
\hline & Mean & 9.7 & 10.1 & 9.9 & & & & \\
\hline \multirow[t]{4}{*}{ Fat } & 50 & 6.4 & 6.1 & $6.3^{\mathrm{A}}$ & & & & \\
\hline & 80 & 15.6 & 12.5 & $14.1^{\mathrm{B}}$ & 0.362 & 0.001 & 0.001 & 0.062 \\
\hline & 105 & 23.5 & 18.7 & $21.1^{c}$ & & & & \\
\hline & Mean & $15.2^{\mathrm{B}}$ & $12.4^{\mathrm{A}}$ & 13.8 & & & & \\
\hline \multirow[t]{4}{*}{ Ash } & 50 & 1.0 & 1.0 & $1.0^{A}$ & & & & \\
\hline & 80 & 1.7 & 1.8 & $1.7^{\mathrm{B}}$ & 0.041 & 0.001 & 0.119 & 0.459 \\
\hline & 105 & 2.5 & 2.7 & $2.6^{C}$ & & & & \\
\hline & Mean & 1.7 & 1.8 & 1.8 & & & & \\
\hline \multirow[t]{4}{*}{ Water } & 50 & 23.8 & 23.8 & $23.8^{\mathrm{A}}$ & & & & \\
\hline & 80 & 37.7 & 36.8 & $37.3^{B}$ & 0.445 & 0.001 & 0.390 & 0.186 \\
\hline & 105 & 45.6 & 47.8 & $46.7^{c}$ & & & & \\
\hline & Mean & 35.5 & 36.1 & 35.8 & & & & \\
\hline
\end{tabular}

${ }^{1}$ see Table 1; ${ }^{A B C}$, abc means with different superscipts within a row (body weight) or column (diet/group) are significantly different at $P<0.01$ or $P<0.05$, respectively

There were significant differences among pigs from group C and GM in empty body weight (EBW) and carcass weight. The EBW of the $\mathrm{C}$ pigs was higher $(P=0.029)$ compared with the GM pigs (74.1 vs $73.1 \mathrm{~kg}$; Table 4). Similarly, the carcass weight of the $C$ pigs was higher $(P=0.001)$ than of the GM pigs (62.7 vs $61.0 \mathrm{~kg})$. Along with increasing EBW, the carcass chemical components of all pigs (group $\mathrm{C}$ and GM) increased $(P<0.001)$. However, only the fat content in the carcass of pigs fed grass meal was lower by $18.5 \%(P=0.001)$ than of pigs fed the $\mathrm{C}$ diet.

Regardless of group (C or GM), along with increasing EBW the carcass chemical components increased $(P=0.001)$, however, only the fat content in the carcass of pigs fed GM diet was lower by $18.5 \%(P=0.001)$ than of pigs fed $\mathrm{C}$ diet. 
Table 5. Weight (kg) of musculus longissimus dorsi (MLD) and concentration (\%) of intramuscular fat (IMF) and SFA, MUFA, PUFA and particular fatty acids of pigs

\begin{tabular}{|c|c|c|c|c|c|c|c|c|c|c|c|c|c|c|c|c|c|}
\hline \multirow{2}{*}{ Indices } & \multirow{2}{*}{$\begin{array}{l}\text { Body } \\
\text { weight } \\
\text { (BW) }\end{array}$} & \multicolumn{2}{|c|}{ Diet/group $^{1}$} & \multirow[b]{2}{*}{ Mean } & \multirow[b]{2}{*}{ SEM } & \multicolumn{3}{|c|}{ Significance } & \multirow[b]{2}{*}{ Indices } & \multirow{2}{*}{$\begin{array}{l}\text { Body } \\
\text { weight } \\
\text { (BW) }\end{array}$} & \multicolumn{2}{|c|}{ Diet/group 1} & \multirow[b]{2}{*}{ Mean } & \multirow[b]{2}{*}{ SEM } & \multicolumn{3}{|c|}{ Significance } \\
\hline & & C & GM & & & BW & diet & $\begin{array}{l}\text { BW } x \\
\text { diet }\end{array}$ & & & $\mathrm{C}$ & GM & & & BW & diet & $\begin{array}{l}\text { BW } x \\
\text { diet }\end{array}$ \\
\hline \multirow[t]{4}{*}{ MLD } & 50 & 1.28 & 1.21 & $1.25^{\mathrm{A}}$ & & & & & C18:1 n-9 & 50 & 40.02 & 41.62 & $40.82^{\mathrm{A}}$ & & & & \\
\hline & 80 & 2.09 & 1.80 & $1.95^{\mathrm{B}}$ & 0.049 & 0.001 & 0.068 & 0.661 & & 80 & 43.09 & 44.32 & $43.70^{B}$ & 0.956 & 0.009 & 0.092 & 0.841 \\
\hline & 105 & 3.85 & 3.68 & $3.76^{\mathrm{C}}$ & & & & & & 105 & 44.44 & 44.58 & $44.51^{\mathrm{B}}$ & & & & \\
\hline & Mean & 2.41 & 2.23 & 2.32 & & & & & & Mean & 42.52 & 43.50 & 43.01 & & & & \\
\hline \multirow[t]{4}{*}{ IMF } & 50 & 1.2 & 0.8 & $1.0^{A}$ & & & & & C18:2 n-6 & 50 & 16.00 & 17.00 & $16.50^{\mathrm{B}}$ & & & & \\
\hline & 80 & 2.2 & 1.8 & $2.0^{B}$ & 0.245 & 0.001 & 0.003 & 0.939 & & 80 & 9.87 & 10.32 & $10.09^{A}$ & 0.475 & 0.001 & 0.081 & 0.347 \\
\hline & 105 & 2.6 & 2.1 & $2.4^{\mathrm{C}}$ & & & & & & 105 & 7.38 & 8.18 & $7.78^{\mathrm{A}}$ & & & & \\
\hline & Mean & $2.0^{B}$ & $1.6^{\mathrm{A}}$ & 1.8 & & & & & & Mean & 11.08 & 11.60 & 11.46 & & & & \\
\hline \multirow[t]{4}{*}{$\mathrm{SFA}^{2}$} & 50 & 37.1 & 34.9 & $36.0^{\mathrm{a}}$ & & & & & C18:3 n-3 & 50 & 0.50 & 0.58 & 0.54 & & & & \\
\hline & 80 & 38.5 & 36.8 & $37.7^{\mathrm{b}}$ & 0.658 & 0.014 & 0.024 & 0.114 & & 80 & 0.51 & 0.61 & 0.56 & 0.034 & 0.823 & 0.047 & 0.961 \\
\hline & 105 & 40.1 & 38.4 & $39.2^{b}$ & & & & & & 105 & 0.46 & 0.58 & 0.52 & & & & \\
\hline & Mean & $38.6^{a}$ & $36.7^{b}$ & 37.6 & & & & & & Mean & $0.49^{a}$ & $0.59^{b}$ & 0.54 & & & & \\
\hline \multirow[t]{4}{*}{ MUFA $^{2}$} & 50 & 42.8 & 45.0 & $43.9^{A}$ & & & & & C20:0 & 50 & 0.09 & 0.11 & 0.10 & & & & \\
\hline & 80 & 46.2 & 48.0 & $47.1^{\mathrm{B}}$ & 0.859 & 0.001 & 0.091 & 0.294 & & 80 & 0.10 & 0.10 & 0.10 & 0.011 & 0.777 & 0.458 & 0.896 \\
\hline & 105 & 48.1 & 48.1 & $48.1^{\mathrm{B}}$ & & & & & & 105 & 0.11 & 0.12 & 0.12 & & & & \\
\hline & Mean & 45.7 & 47.0 & 46.4 & & & & & & Mean & 0.10 & 0.11 & 0.11 & & & & \\
\hline \multirow[t]{4}{*}{ PUFA $^{2}$} & 50 & 19.0 & 20.1 & $19.5^{\mathrm{B}}$ & & & & & C20:1 n-7 & 50 & 0.61 & 0.58 & 0.60 & & & & \\
\hline & 80 & 12.0 & 12.8 & $12.4^{\mathrm{A}}$ & 0.574 & 0.001 & 0.047 & 0.218 & & 80 & 0.63 & 0.64 & 0.64 & 0.041 & 0.732 & 0.478 & 0.749 \\
\hline & 105 & 9.4 & 10.3 & $9.9^{A}$ & & & & & & 105 & 0.63 & 0.54 & 0.59 & & & & \\
\hline & Mean & $13.5^{\mathrm{a}}$ & $14.4^{b}$ & 13.9 & & & & & & Mean & 0.62 & 0.58 & 0.61 & & & & \\
\hline \multirow[t]{4}{*}{ C14:0 } & 50 & 1.21 & 1.15 & 1.18 & & & & & C20:3 n-6 & 50 & 0.44 & 0.42 & $0.43^{b}$ & & & & \\
\hline & 80 & 0.98 & 1.10 & 1.04 & 0.049 & 0.071 & 0.091 & 0.041 & & 80 & 0.31 & 0.38 & $0.35^{\mathrm{a}}$ & 0.021 & 0.008 & 0.065 & 0.118 \\
\hline & 105 & 1.35 & 1.16 & 1.26 & & & & & & 105 & 0.25 & 0.26 & $0.25^{\mathrm{a}}$ & & & & \\
\hline & Mean & 1.18 & 1.14 & 1.16 & & & & & & Mean & 0.33 & 0.35 & 0.34 & & & & \\
\hline \multirow[t]{4}{*}{ C16:0 } & 50 & 23.49 & 22.06 & $22.78^{\mathrm{A}}$ & & & & & C20:4 n-6 & 50 & 2.03 & 2.05 & $2.04^{b}$ & & & & \\
\hline & 80 & 24.18 & 23.00 & $23.59^{B}$ & 0.245 & 0.002 & 0.044 & 0.115 & & 80 & 1.33 & 1.44 & $1.39^{a}$ & 0.239 & 0.044 & 0.504 & 0.162 \\
\hline & 105 & 25.10 & 24.18 & $24.64^{B}$ & & & & & & 105 & 1.29 & 1.32 & $1.31^{\mathrm{a}}$ & & & & \\
\hline & Mean & $24.26^{\mathrm{a}}$ & $23.08^{b}$ & 23.67 & & & & & & Mean & 1.55 & 1.60 & 1.58 & & & & \\
\hline \multirow{4}{*}{$\begin{array}{l}\text { C16:1 } \\
n-7\end{array}$} & 50 & 2.18 & 2.80 & 2.49 & & & & & C18:2 n-6/ & 50 & 32.0 & 29.3 & $30.7^{\mathrm{B}}$ & & & & \\
\hline & 80 & 2.47 & 3.03 & 2.75 & 0.190 & 0.099 & 0.038 & 0.288 & C18:3n-3 & 80 & 19.4 & 16.9 & $18.2^{\mathrm{A}}$ & 0.648 & 0.001 & 0.091 & 0.426 \\
\hline & 105 & 3.00 & 3.00 & 3.00 & & & & & & 105 & 16.0 & 14.1 & $15.1^{\mathrm{A}}$ & & & & \\
\hline & Mean & $2.55^{\mathrm{A}}$ & $2.94^{B}$ & 2.75 & & & & & & Mean & 22.5 & 20.1 & 21.3 & & & & \\
\hline \multirow[t]{4}{*}{ C18:0 } & 50 & 12.28 & 11.58 & 11.93 & & & & & PUFA/ & 50 & 0.51 & 0.57 & $0.54^{\mathrm{A}}$ & & & & \\
\hline & 80 & 13.25 & 12.64 & 12.95 & 0.333 & 0.482 & 0.619 & 0.306 & SFA $^{2}$ & 80 & 0.31 & 0.36 & $0.33^{B}$ & 0.024 & 0.001 & 0.102 & 0.359 \\
\hline & 105 & 13.51 & 12.90 & 13.21 & & & & & & 105 & 0.23 & 0.27 & $0.25^{\mathrm{B}}$ & & & & \\
\hline & Mean & 13.01 & 12.37 & 12.69 & & & & & & Mean & 0.35 & 0.40 & 0.38 & & & & \\
\hline
\end{tabular}

${ }^{1}$ see Table $1 ;{ }^{2}$ see Table 2; ${ }^{A B}$, ab means with different superscipts within a row (body weight) or column (diet/group) are significantly different at $P<0.01$ or $P<0.05$, respectively

Fatty acid concentrations in the musculus longissimus dorsi

Pigs of the GM group showed a tendency towards a lower $(P=0.068)$ mass of the MLD and lower $(P<0.003)$ content of IMF compared with the control animals $(2.23$ vs $2.41 \mathrm{~kg}$ and $1.6 \%$ vs $2.0 \%$, respectively; Table 5). The concentration of
SFA was lower $(P=0.024)$, however, the PUFA concentration was higher $(P=0.047)$ in the GM than C pigs (36.7\% vs $38.6 \%$ and $14.4 \%$ vs $13.5 \%$, respectively). Pigs of the GM group had lower $(P=0.044)$ concentrations of palmitic acid (C16:0), while the concentrations of palmitoleic $(\mathrm{C} 16: 1 \mathrm{n}-7)$ were higher $(P=0.038)$ compared with the $\mathrm{C}$ pigs 
(23.08\% vs $24.26 \%$ and $2.94 \%$ vs $2.55 \%$, respectively). The diets had no effect on the concentration of linoleic acid (C18:2 n-6, average 11.46\%), however, the concentration of linolenic acid (C18:3 n-3) was lower $(P=0.047)$ in the $C$ pigs compared with the GM pigs $(0.49 \%$ vs $0.59 \%)$. For this reason the GM pigs showed a tendency towards a higher $(P=0.102)$ PUFA/SFA ratio and tended to have a lower $(P=0.091) \mathrm{C} 18: 2 \mathrm{n}-6 / \mathrm{C} 18: 3 \mathrm{n}-3$ ratio than $\mathrm{C}$ pigs ( 0.40 vs 0.35 and 22.5 vs 20.1 , respectively). As the BW of pigs increased from 50 to $105 \mathrm{~kg}$, the concentration of SFA and MUFA increased from $36.0 \%$ to $39.2 \%(P=0.014)$ and from $43.9 \%$ to $48.1 \%$ $(P=0.001)$, respectively, while the concentration of PUFA decreased $(P<0.001)$ from $19.5 \%$ to $9.9 \%$, respectively. The concentration of palmitic acid (C16:0) was higher $(P=0.002)$ in pigs slaughtered at 80 and $105 \mathrm{~kg}$ BW compared with those slaughtered at $50 \mathrm{~kg} \mathrm{BW}$ (average $24.12 \%$ vs $22.78 \%$, respectively). The pigs slaughtered at 80 and $105 \mathrm{~kg} \mathrm{BW}$ had higher $(P=0.009)$ concentrations of oleic acid $(\mathrm{C} 18: 1$ $\mathrm{n}-9$ ) than those slaughtered at $50 \mathrm{~kg} \mathrm{BW}$ (average $44.10 \%$ vs $40.82 \%$, respectively). The concentration of palmitoleic acid $(\mathrm{C} 16: 1 \mathrm{n}-7)$ tended $(P=0.099)$ to increase from $2.5 \%$ at $50 \mathrm{~kg} \mathrm{BW}$ to $3.0 \%$ at $105 \mathrm{~kg}$ BW. The concentration of C18:2 n-6, C18:3 n-3, and C20:4 n-6 decreased during growth of the pigs from 50 to $105 \mathrm{kgBW}$, as the heaviest animals had the lowest $(P<0.05)$ concentration of these fatty acids.

The PUFA/SFA and C18:2 n-6/C18:3 n-3 ratios in the pigs at $50 \mathrm{~kg} \mathrm{BW}$ were higher $(P=0.001)$ than in those at 80 and $105 \mathrm{~kg} \mathrm{BW}(0.54$ vs 0.30 and 30.7 vs 16.7 , respectively).

\section{Discussion}

The contents of fat and unsaturated fatty acids, the PUFA/SFA and C18:2 n-6/C18:3n-3 ratios in pork fat influence the meat's nutritional value for humans (WHO/FAO, 2003). Recently, research has focused on how to modify the fat content and the fatty acid composition of pork to improve its nutritional quality. Grass meal is an alternative feed component with a high content of unsaturated fatty acids.

Our study tried to show how supplementation of conventional feed with grass meal would impact growth, carcass chemical components, fat content and fatty acid composition of the MLD in growing pigs. In our study, the pigs consuming grass meal feed grew more slowly, but had less fat in the carcass than the pigs fed the commercial diet. However, they stayed in the experiment for about 5 days longer than $\mathrm{C}$ pigs and, consequently, they consumed more feed (for about 12\%). This resulted in similar total consumption of metabolizable energy (2812 MJ) and digestible protein $(31.8 \mathrm{~kg})$. Moreover, due to a similar ratio of essential amino acids, they also consumed a similar total amount of lysine, methionine, threonine and tryptophan as the $\mathrm{C}$ pigs $(1.7,0.53,0.96$ and $0.29 \mathrm{~kg}$, respectively). The differences in the body fat content of the pigs were in agreement with the results of Skiba et al. (2006) in pigs in the same weight range. During growth, the proportion of energy available for fat deposition in pigs fed a conventional diet increases so that the rate of de novo fatty acid synthesis is increased (Enser et al., 1996). However, during growth the proportion of energy available for fat deposition in pigs fed grass meal is lower and, the rate of de novo fatty acid synthesis is decreased.

Hansen et al. (2006) showed that feeding pigs diets with clover silage can improve carcass and meat quality. In comparison with conventional feeding, the experimental carcasses were characterized by a significantly higher meat content (by $8.2 \%$ ), as well as thinner fat around the loin (by 22\%).

Moreover, the literature data indicate that a lower body fat content can also reduce, to some extent, the IMF content in the meat. In the present study the IMF content in the MLD was lower in the pigs fed the GM diet, doubtless due to the lower energy content of the feed. This was also found in a study on pigs (Skiba et al., 2009) and steers (Schoonmaker et al., 2004). Moreover, Scerra et al. (2007) showed that feeding ewes with pasture increased the PUFA content in the IMF of their lambs compared with diets consisting of concentrate. Sundrum et al. (2000) found that the IMF content in the MLD can be increased by a reduction of the crude protein (lysine)-to-energy ratio in the diet without increasing backfat thickness.

Our study was also focused on the effects of grass meal in the diet on the fatty acid composition in the MLD. The higher content of PUFA in the MLD of pigs fed a GM diet was due to a higher level of these fatty acids in the consumed diet. The grass meal diet contained $13.8 \mathrm{~g} \cdot \mathrm{kg}^{-1}$ PUFA (approximately 63\% total fatty acids), which resulted in higher levels of PUFA (mainly linolenic and linoleic acids) in the IMF of the MLD. Our results are in accordance to the data from growing pigs fed fresh grass (Jakobsen, 1995), grass silage (Świątkiewicz and Hanczakowska, 2007) and clover silage (Johansson et al., 2002). In general, the relative levels of fatty acids in the tissues reflect the content of these fatty acids in the feed (Skiba et al., 2015). This has been confirmed in feeds containing highly unsaturated components such as fish, 
rapeseed, linseed oil (Kouba and Sellier, 2011; Sobol et al., 2015) or highly saturated components such as tallow fat (Flachowsky et al., 2008; Raj et al., 2010).

The low fat content in the MLD is important when considering the nutritive value of meat from pigs fed a grass meal diet. In our study, the IMF content of pigs fed the grass meal diet was low, which means lower concentrations of SFA and higher concentrations of MUFA and PUFA. The proportion of PUFA in the meat fat was higher in the pigs fed the GM diet, mainly due to the higher level of linolenic acid in the grass meal than in the commercial diet. Hansen et al. (2006) reported that pigs fed a diet with grass or clover silage have a higher concentration of PUFA, but a lower concentration of MUFA in the IMF. The MLD of pigs fed the grass meal diet had a lower IMF concentration and levels of SFA and palmitic acid, which are thought to be a public health risk.

The difference in the palmitic acid content between groups could be attributed to the different level of this fatty acid in the diet consumed by pigs (Valvo et al., 2005).

Our study showed that the concentrations of SFA and MUFA in the MLD increased and, simultaneously, the concentration of PUFA decreased with increasing BW. Similar results were presented in the study by Kouba and Bonneau (2009).

In the present study we found a tendency towards obtaining higher PUFA/SFA ratios in the IMF of the MLD when pigs were fed the diet supplemented with grass meal. Thus, from a nutritional point of view, the meat of these pigs was characterized by a favourable fatty acid profile for humans. The change in the PUFA/SFA ratio was in agreement with the study by Johansson et al. (2002), who added red clover silage to the diet, and with the study by Jakobsen (1995), who added fresh grass and herbs to the diet.

The higher concentration of $\mathrm{C} 18: 3 \mathrm{n}-3$ acid in the MLD of pigs fed the GM diet resulted in a tendency towards a lower linoleic/linolenic acid ratio compared with the C pigs. Similarly, Świątkiewicz and Hanczakowska (2007) showed that the PUFA $\mathrm{n}-6 / \mathrm{n}-3$ ratio decreased by $2.4 \%$ in the backfat of pigs fed diets with grass silages compared with whole plant maize silage.

\section{Conclusions}

Pigs fed a commercial diet diluted with grass meal grew more slowly, but the carcass contained less fat and had a different fatty acid composition. The concentrations of saturated fatty acids, polyunsaturated fatty acids and the ratio of linoleic/lino- lenic acid in the musculus longissimus dorsi were more beneficial for humans when pigs were fed the grass meal than the commercial diet.

\section{References}

AOAC, 2011. Association of Official Analytical Chemists, Official Methods of Analysis. $18^{\text {th }}$ Edition. Gaithersburg, MD

Degussa A.G., 2001. Standardized lleal Digestibility of Amino Acids in Pigs. Frankfurt am Main (Germany)

Enser M., Hallett K., Hewitt B., Fursey G.A.J., Wood J.D., 1996. Fatty acid content and composition of English beef, lamb and pork at retail. Meat Sci. 42, 443-456

Flachowsky G., Schulz E., Kratz R., Glodek P., 2008. Effects of different dietary fat sources on the fatty acid profile of backfat and intramuscular fat of pigs of various sire breeds. J. Anim. Feed Sci. 17, 363-371

Folch J., Lees M., Sloane Stanley G.H., 1957. A simple method for the isolation and purification of lipids from animal tissues. J. Biol. Chem. 226, 497-509

Hansen L.L., Claudi-Magnussen C., Jensen S.K., Andersen H.J., 2006. Effect of organic pig production systems on performance and meat quality. Meat Sci. 74, 605-615

Jakobsen K., 1995. Fatty acids: possibilities of enriching meat with n-3 fatty acids. Meat Focus Int. 4, 286-289

Johansson L., Lundström K., Jonsäll A., 2002. Effects of RN genotype and silage feed on fat content and fatty acid composition of fresh and cooked pork loin. Meat Sci. 60, 17-24

Jonsäll A., Johansson L., Lundström K., 2000. Effects of red clover silage and RN genotype on sensory quality of prolonged frozen stored pork (M. Longissimus dorsi). Food Qual. Prefer. 11, 371-376

Kotarbińska M., 1971. The chemical composition of the body in growing pigs (in Polish). Rocz. Nauk Rol. B 93, 129-135

Kouba M., Bonneau M., 2009. Compared development of intermuscular and subcutaneous fat in carcass and primal cuts of growing pigs from 30 to $140 \mathrm{~kg}$ body weight. Meat Sci. 81, 270-274

Kouba M., Sellier P., 2011. A review of the factors influencing the development of intermuscular adipose tissue in the growing pig. Meat Sci. 88, 213-220

Raj S., Poławska E., Skiba G., Weremko D., Fandrejewski H., Skomiał J., 2010. The influence of different fatty acids sources in diets on chemical composition of the body and utilization of linoleic and linolenic acids in pigs. Anim. Sci. Pap. Rep. 28, 355-362

Regulation of the Ministry of Agriculture and Rural Development, 2003 (in Polish). Dz. U. no 167, pos. 1629

RFES (Rostock Feed Evaluation System), 2003. Reference numbers of feed value and requirement on the base of net energy. W. Jentsch, A. Chudy, M. Beyer (Editors). FBN, WGL, Oskar Kellner. Dummerstorf (Germany)

Scerra M., Caparra P., Foti F., Galofaro V., Sinatra M.C., Scerra V., 2007. Influence of ewe feeding systems on fatty acid composition of suckling lambs. Meat Sci. 76, 390-394

Schoonmaker J.P., Fluharty F.L., Loerch S.C., 2004. Effect of source and amount of energy and rate of growth in the growing phase on adipocyte cellurality and lipogenic activity in the intramuscular and subcutaneous fat depots of Holstein steers. J. Anim. Sci. 82, 137-148

Skiba G., Poławska E., Sobol M., Raj S., Weremko D., 2015. Omega-6 and omega-3 fatty acids metabolism pathways in the body of pigs fed diets with different sources of fatty acids. Arch. Anim. Nutr. 69, 1-16 
Skiba G., Raj S., Weremko D., Fandrejewski H., 2006. The compensatory response of pigs previously fed a diet with an increased fibre content. 2. Chemical body components and composition of daily gain. J. Anim. Feed Sci. 15, 403-415

Skiba G., Raj S., Weremko D., Fandrejewski H., 2009. Protein, nucleic acid content and activity of $\mu$ - and $m$-calpain in the longissimus dorsi muscle as affected by protein and energy restriction during early growth of pigs. Arch. Anim. Nutr. 63, 149-159

Sobol M., Skiba G., Raj S., 2015. Effect of $n-3$ polyunsaturated fatty acid intake on its deposition in the body of growing-finishing pigs. Anim. Feed Sci. Tech. 208, 107-118

Sundrum A., Bütfering L., Henning M., Hoppenbrock K.H., 2000. Effects of on-farm diets for organic pig production on performance and carcass quality. J. Anim. Sci. 78, 1199-1205
Świątkiewicz M., Hanczakowska E., 2007. Chosen indices of meat and carcass quality of pigs fed grass or maize silages supplemented with herb mixture. Pol. J. Food Nutr. Sci. 57, 547-550

Valvo M.A., Lanza M., Bella M., Fasone V., Scerra M., Biondi L., Priolo A., 2005. Effect of ewe feeding system (grass v. concentrate) on intramuscular fatty acids of lambs raised exclusively on maternal milk. Anim. Sci. 81, 431-436

Webb E.C., O'Neill H.A., 2008. The animal fat paradox and meat quality. Meat Sci. 80, 28-36

WHO/FAO, 2003. Diet nutrition and the prevention of chronic diseases. Report of a Joint WHO/FAO Expert Consultation. WHO Technical Report Series 916. Geneva (Switzerland) 